\title{
Variabilidade na produção de embriões Mus domesticus domesticus*
}

\author{
LUCIANE PANSARDI CABREIRA BAPTISTA \\ José Luiz Rodrigues (Orientador - UFRGS)
}

Banca: Alceu Mezzalira (UDESC), Adriana Bos Mikich (PUC), Ricardo Azambuja (PUC)

O objetivo do experimento foi verificar a variabilidade na produção de embriões Mus domesticus domesticus linhagem CF1, determinando as taxas de clivagem e de desenvolvimento embrionário até o estádio de blastocisto e blastocisto eclodido. Foram obtidas 4196 estruturas de 74 fêmeas, acasaladas individualmente com 5 diferentes machos da mesma linhagem. Os zigotos de cada fêmea doadora foram cultivados in vitro em meio KSOM, em atmosfera gasosa úmida com 5 $\%$ de $\mathrm{CO} 2$ à temperatura de $37^{\circ} \mathrm{C}$ durante 120 horas. As fêmeas foram distribuídas em cinco grupos (G1 a G5) de acordo com o número de estruturas coletadas e conforme o número de tratamentos superovulatórios a que foram submetidas. A análise dos dados revelou a existência de variabilidade na produção de embriões e na eficiência $(\mathrm{P}<0,05)$ das fêmeas em resposta ao primeiro tratamento superovulatório. Os machos também influenciaram nos resultados $(\mathrm{p}<0,05)$ destacando-se o de número cinco (5) como o de maior potencial na produção de embriões. Os resultados evidenciaram uma variabilidade no número e na capacidade de desenvolvimento embrionário na espécie Mus domesticus domesticus linhagem CF1, considerando-se a fêmea doadora, o macho empregado e a reutilização das fêmeas que fracassaram no primeiro acasalamento.

Descritores: variabilidade, zigotos, cultivo, clivagem, pré-implantação. 


\title{
Variability in the Mus domesticus domesticusembryo production**
}

\author{
LUCIANE PANSARDI CABREIRA BAPTISTA \\ José Luiz Rodrigues (Adviser - UFRGS)
}

Committee: Alceu Mezzalira (UDESC), Adriana Bos Mikich (PUC), Ricardo Azambuja (PUC)

The aim of this experiment was to verify the variability of the Mus domesticus domesticus (CF1 strain) to produce viable embryo. The females were mated individually with five different males and from 74 donors 4196 structures were collected. All zygotes of each female donor were in vitro cultured in $\mathrm{KSOM}$ medium, incubated at $37^{\circ} \mathrm{C}$ in a $5 \% \mathrm{CO} 2$ air humidified atmosphere during $120 \mathrm{~h}$. The females were distributed in five groups (G1- G5) according to the number of collected structures and according to the number of superovulatories treatments that they were submitted. The analysis of the data revealed a variability in the embryo production capacity among the females and in the response to the first superovulatory treatment $(\mathrm{p}<0.05)$. The males also influenced the results $(\mathrm{p}<0.05)$ and the number five $(5)$ stood out from the others for its major potential in the embryo production. The embryonic cleavage and the development rates to the blastocyst and hatched blastocyst stage were determined. The results revealed the variability in the number of produced embryos and in its development competence to reach the hatched blastocyst stage taking into account the female donor and the male.

Key words: variability, zygotes, culture, cleavage, preimplantation.

\footnotetext{
**Master's Thesis \# 375 (Field: Theriogenology). 39p. Graduate Program in Veterinary Sciences, Faculdade de Veterinária, Universidade
} Federal do Rio Grande do Sul (UFRGS), Porto Alegre/Brazil. CORRESPONDENCE: L.P.C. Baptista [emirrobinson@uol.com.br]. 